\title{
Synthesis, Anti-Proliferative Evaluation and Mechanism of 4-Trifluoro Methoxy Proguanil Derivatives with Various Carbon Chain Length
}

\author{
Simeng Xu ${ }^{1,+}$, Yufang Cao ${ }^{1,+}$, Yu Luo ${ }^{2}$, Di Xiao ${ }^{1}$, Wei Wang ${ }^{2} \mathbb{C}$, Zhiren Wang ${ }^{1}$ and Xiaoping Yang ${ }^{1, * \mathbb{C}}$ \\ 1 Key Laboratory of Study and Discovery of Small Targeted Molecules of Hunan Province, Key Laboratory \\ of Protein Chemistry and Developmental Biology of Fish of Ministry of Education, Department of Pharmacy, \\ School of Medicine, Hunan Normal University, Changsha 410205, China; simeng.xu@hunnu.edu.cn (S.X.); \\ yufang.cao@hunnu.edu.cn (Y.C.); dixiao@hunnu.edu.cn (D.X.); zhirenwang@foxmail.com (Z.W.) \\ 2 TCM and Ethnomedicine Innovation \& Development International Laboratory, Innovative Material Medical \\ Research Institute, School of Pharmacy, Hunan University of Chinese Medicine, Changsha 410208, China; \\ luoyu1998111@163.com (Y.L.); wangwei402@hotmail.com (W.W.) \\ * Correspondence: xiaoping.yang@hunnu.edu.cn; Tel.: +86-158-7406-6132 \\ + These authors contributed equally to this work.
}

check for updates

Citation: Xu, S.; Cao, Y.; Luo, Y.; Xiao, D.; Wang, W.; Wang, Z.; Yang, X. Synthesis, Anti-Proliferative Evaluation and Mechanism of 4-Trifluoro Methoxy Proguanil Derivatives with Various Carbon Chain Length. Molecules 2021, 26 , 5775. https://doi.org/10.3390/ molecules26195775

Academic Editor: Qiao-Hong Chen

Received: 16 August 2021

Accepted: 20 September 2021

Published: 24 September 2021

Publisher's Note: MDPI stays neutral with regard to jurisdictional claims in published maps and institutional affiliations.

Copyright: (c) 2021 by the authors. Licensee MDPI, Basel, Switzerland. This article is an open access article distributed under the terms and conditions of the Creative Commons Attribution (CC BY) license (https:/ / creativecommons.org/licenses/by/ $4.0 /)$.
Abstract: Among the known biguanide drugs, proguanil has the best antiproliferative activity. In contrast, newly synthesized biguanide derivatives containing fluorine atoms have excellent biological activity, among which trifluoromethoxy compounds show the strongest ability. Preliminary work in our laboratory exhibited that n-heptyl containing proguanil derivatives on one alkyl chain side have better biological activity than those with a shorter carbon chain. However, the relationship between the length of the carbon chain and the activity of the compounds is unknown. In this study, we synthesized 10 new trifluoromethoxy-containing proguanil derivatives with various carbon chain lengths. The phenyl side is fixed as the trifluoromethoxy group with change of carbon chain length in alkyl chain side. It was found that the anti-cancer abilities of $5 \mathrm{C}-8 \mathrm{C}$ with n-pentyl to n-octyl groups was significantly better than that of proguanil in the five human cancer cell lines. The colony formation assay demonstrated that $6 \mathrm{C}-8 \mathrm{C}$ at 0.5 to $1.0 \mu \mathrm{M}$ significantly inhibited the colony formation of human cancer cell lines, much stronger than that of proguanil. Pharmacologically, $8 \mathrm{C}$ activates AMPK, leading to inactivation of the mTOR/p70S6K/4EBP1 pathway. Thus, these novel compounds have a great potential for developing new anti-cancer candidates.

Keywords: biguanide; anti-cancer; trifluoromethoxy; AMPK

\section{Introduction}

According to the data of The World Health Organization's International Agency for Research on Cancer, it is estimated that there were 19.29 million new cancer cases and 9.96 million cancer deaths worldwide in 2020 [1]. Thus, finding efficient and safe targeted anti-tumor drugs is still an arduous and urgent task. Recently, biguanides have attracted considerable attentions due to their excellent biologically activities. Clinically, buformin and metformin have been used to treat diabetes [2,3], and proguanil is used to treat malaria [4]. In contrast, the anti-proliferation activity of biguanides, especially metformin, has stimulated great interests but has not been used in clinic yet [5]. Furthermore, preclinical studies have shown that the effective concentration of metformin in inhibiting cancer cell proliferation is at millimolar level [6], which is difficult to achieve in vivo through routine oral administration route, making it difficult for metformin to be used as a clinical antitumor agent [7]. Moreover, studies have reported that proguanil has the strongest inhibitory effect in bladder cancer and colon cancer cell lines among biguanides [8]. Therefore, the structural optimization of proguanil has the great potential to find more effective antiproliferative compounds. 
Fluorine-containing derivatives are reported to have excellent activity including anti-proliferation and anti-cancer capabilities $[9,10]$. Among the fluorine-containing substituents, trifluoromethoxy has a significant impact on enhancing biological activity, so it has been received widespread attention [11,12]. Compared with other fluorine-containing substituents, trifluoromethoxy is relatively inert and exhibits stronger stability under heating, acidic or alkaline conditions $[13,14]$. In recent years, chemical drugs containing trifluoromethoxy have been approved by the US Food and Drug Administration (FDA) for the treatment of tuberculosis (Pretomanid) and basal cell carcinoma (Sonidegib) (Figure 1). Pretomanid, approved by the US FDA, is used in combination with bedaquiline and linezolid to treat specific highly drug-resistant tuberculosis (TB) patients [15]. Sonidegib is approved by the FDA for use in adult patients with locally advanced basal cell carcinoma [16]. In the previous research of our group, it was found that when there is n-heptyl substitution on the alkyl side of fluorine-containing proguanils, these compounds exhibit better antiproliferative activity [17], but the relationship between alkyl chain length and antitumor activity is not clear. In this study, a trifluoromethoxy group was introduced at the para position of the phenyl group with alteration of the carbon chain length on the side of the biguanide group (Figure 2). It was found that the anti-proliferative activity of $5 \mathrm{C}-\mathbf{8 C}$ (n-pentyl to n-octyl) was significantly improved compared to proguanil, and when the carbon chain length reached $9 \mathrm{C}$ (n-nonyl), the anti-proliferative activity was significantly reduced, indicating there is an optimized carbon atom length. Furthermore, it is still unknown whether these new biguanide derivatives affect the molecular signal pathways or not. Thus, anti-tumor mechanism of representative biguanide derivative was further investigated.

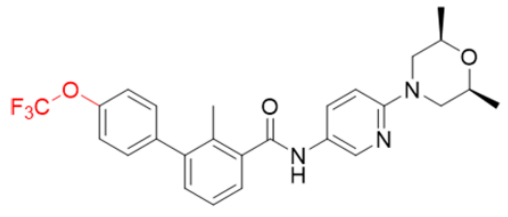

Sonidegib<smiles>O=[N+]([O-])c1cn2c(n1)OCC(OCc1ccc(OC(F)(F)F)cc1)C2</smiles>

Pretomanid

Figure 1. Marketed chemical drugs containing trifluoromethoxy.

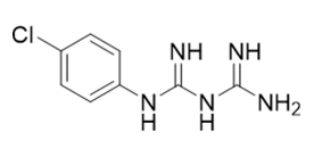

Cll<smiles>N=C(N)NC(=N)NC(=N)Nc1ccc(OC(F)(F)F)cc1</smiles>

2C-10C, $12 \mathrm{C}$

Figure 2. Design strategy of 4-(trifluoromethoxy) aniline derivatives.

\section{Results}

The target derivatives $\mathbf{2 C}-\mathbf{1 0 C}$ and $\mathbf{1 2 C}$ were synthesized according to the method as shown in Scheme 1. The commercially available compound 4- (trifluoromethoxy) aniline was firstly reacted with sodium dicyandiamide at $80{ }^{\circ} \mathrm{C}$ to obtain the intermediate. It was then reacted with corresponding alkylamines in tetrahydrofuran at $40{ }^{\circ} \mathrm{C}$ until the intermediate compound was fully reacted. Finally, after $\mathrm{HCl}$ solution was added and stirred for $30 \mathrm{~min}$, ethylenediaminetetraacetic acid (EDTA) solution was dropped into the reaction mixture and filtered to obtain target derivatives $\mathbf{2 C}-\mathbf{1 0 C}$ and $\mathbf{1 2 C}$. The main purpose of this study is to investigate whether the anti-proliferative activity of biguanides is increased when one side of the fixed benzene ring is trifluoromethoxy and the other side of the carbon chain lengthens. We synthesized 10 new compounds and determined their $\mathrm{IC}_{50}$ (Table 1). Three bladder cancer cell lines and two ovarian cancer cell lines were exposed to specific concentrations of all compounds to determine their inhibitory effects on cell proliferation. 
Since the anti-proliferation ability of compound $5 \mathrm{C}-8 \mathrm{C}$ was significantly better than that of proguanil, we chose $6 \mathrm{C}, 7 \mathrm{C}$ and $8 \mathrm{C}$ to perform clone formation experiments in three bladder cancer cell lines. As shown Figures 3-5, these compounds between 0.5 to $4.0 \mu \mathrm{M}$ exhibited excellent activities in inhibiting clone formation in these cancer cell lines, similar to the results of MTT.

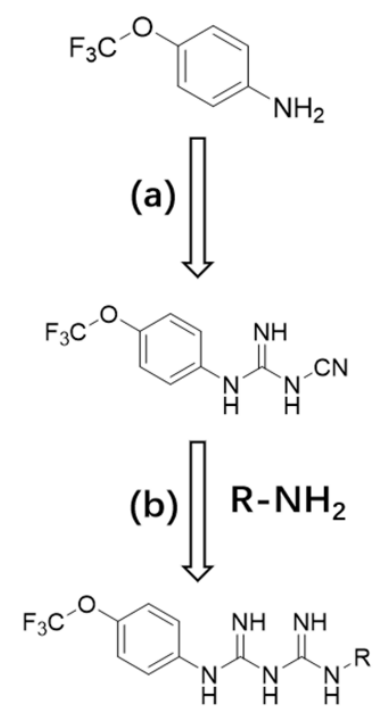

$2 \mathrm{C}-10 \mathrm{C}, 12 \mathrm{C}$
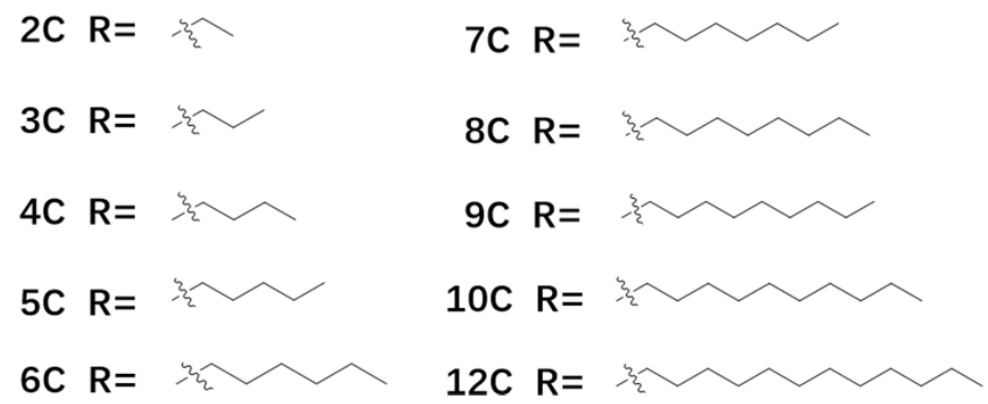

Scheme 1. Synthesis of compounds $\mathbf{2 C}-\mathbf{1 0 C}$ and $\mathbf{1 2 C}$. Reagents and conditions: (a) $\mathrm{NaN}(\mathrm{CN})_{2}, \mathrm{HCl}$, reflux, $80{ }^{\circ} \mathrm{C}, 1 \mathrm{~h}$; (b) $\mathrm{CuSO}_{4} \cdot 5 \mathrm{H}_{2} \mathrm{O}, 40{ }^{\circ} \mathrm{C}, 3 \mathrm{~h}$; monitored by TLC.

Table 1. $\mathrm{IC}_{50}$ values against the biguanide derivatives on cancer cell lines.

\begin{tabular}{cccccc}
\hline \multirow{2}{*}{ Compound } & \multicolumn{5}{c}{ IC $_{\mathbf{5 0}}(\boldsymbol{\mu M}) \pm \mathbf{S D}^{\mathbf{a}, \mathbf{b}}$} \\
\cline { 2 - 6 } & J82 & UMUC3 & T24 & OVCAR3 & SKOV3 \\
\hline Proguanil & $65.6 \pm 5.09$ & $24.5 \pm 2.33$ & $32.6 \pm 2.91$ & $23.1 \pm 1.49$ & $43.5 \pm 3.53$ \\
2C & $5.7 \pm 0.21$ & $3.7 \pm 0.24$ & $9.7 \pm 0.47$ & $4.6 \pm 0.45$ & $11.2 \pm 0.67$ \\
3C & $7.0 \pm 0.84$ & $1.5 \pm 0.17$ & $3.2 \pm 0.24$ & $2.2 \pm 0.21$ & $20.0 \pm 1.74$ \\
4C & $5.0 \pm 0.24$ & $3.9 \pm 0.16$ & $4.1 \pm 0.29$ & $2.0 \pm 0.18$ & $10.5 \pm 0.88$ \\
5C & $2.1 \pm 0.18$ & $3.9 \pm 0.40$ & $1.4 \pm 0.16$ & $1.9 \pm 0.22$ & $9.1 \pm 0.86$ \\
6C & $3.3 \pm 0.33$ & $2.3 \pm 0.21$ & $4.3 \pm 0.48$ & $2.2 \pm 0.20$ & $7.2 \pm 0.62$ \\
7C & $3.3 \pm 0.26$ & $3.5 \pm 0.29$ & $3.3 \pm 0.23$ & $2.1 \pm 0.14$ & $7.4 \pm 0.46$ \\
8C & $2.6 \pm 0.23$ & $3.3 \pm 0.20$ & $3.1 \pm 0.21$ & $3.2 \pm 0.34$ & $5.5 \pm 0.49$ \\
9C & $>100$ & $32.3 \pm 2.54$ & $25.5 \pm 2.16$ & $96.6 \pm 7.41$ & $>100$ \\
10C & $>100$ & $27.1 \pm 1.59$ & $21.5 \pm 1.51$ & $48.9 \pm 3.64$ & $>100$ \\
12C & $>100$ & $25.1 \pm 3.20$ & $18.2 \pm 1.98$ & $43.3 \pm 3.52$ & $>100$ \\
\hline
\end{tabular}

a Cell lines are treated with derivatives for $72 \mathrm{~h} .{ }^{\mathrm{b}} \mathrm{IC}_{50}$ values are the mean of triplicate measurements. 


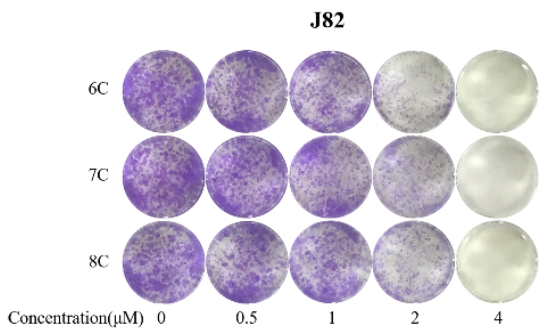

(a)

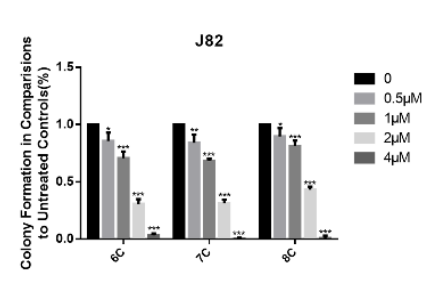

(b)

Figure 3. Evaluation of compound $6 \mathrm{C}, 7 \mathrm{C}$ and $8 \mathrm{C}$ on the clonal colony formation inhibitory effect of J82 cell line. (a) J82 cell line was treated with these compounds at a concentration of $0-4 \mu \mathrm{M}$, and counted with crystal violet staining after 7 days. (b) Quantification of (a) experiment. Use area scan detection at $550 \mathrm{~nm}$ wavelength. The results are the mean $\pm \mathrm{SD}$ of 3 independent experiments. ${ }^{*} p<0.05,{ }^{* *} p<0.01$ and ${ }^{* * *} p<0.001$ versus control (Student's $t$-test). SD, standard deviation.

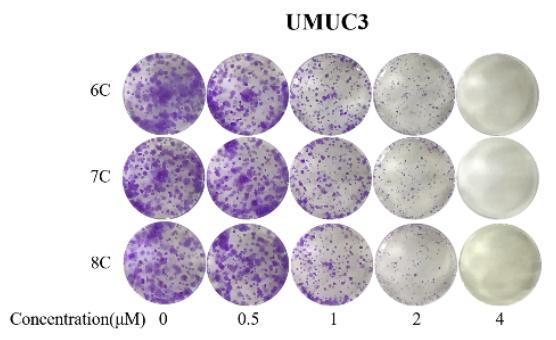

(a)

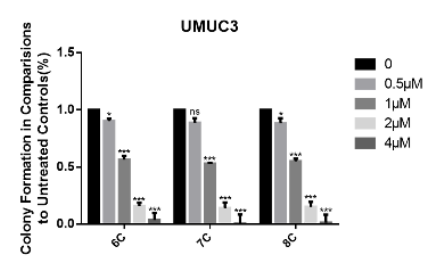

(b)

Figure 4. Evaluation of compound $6 \mathrm{C}, 7 \mathrm{C}$ and $8 \mathrm{C}$ on the clonal colony formation inhibitory effect of UMUC3 cell line. (a) UMUC3 cell line was treated with these compounds at a concentration of 0-4 $\mu \mathrm{M}$, and counted with crystal violet staining after 7 days. (b) Quantification of (a) experiment. Use area scan detection at $550 \mathrm{~nm}$ wavelength. The results are the mean $\pm \mathrm{SD}$ of 3 independent experiments. ${ }^{*} p<0.05$, and ${ }^{* * *} p<0.001$ versus control (Student's $t$-test). SD, standard deviation.

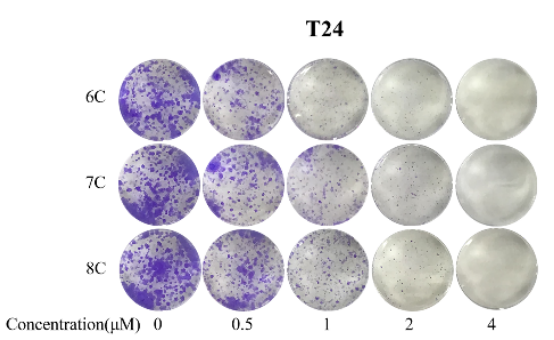

(a)

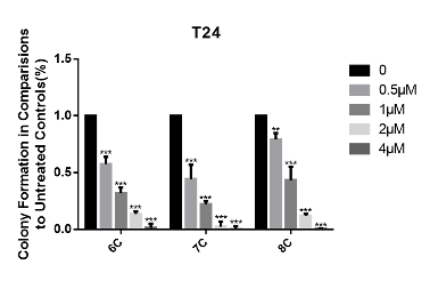

(b)

Figure 5. Evaluation of compound $6 \mathrm{C}, 7 \mathrm{C}$ and $8 \mathrm{C}$ on the clonal colony formation inhibitory effect of T24 cell line. (a) T24 cell line was treated with these compounds at a concentration of $0-4 \mu \mathrm{M}$, and counted with crystal violet staining after 7 days. (b) Quantification of (a) experiment. Use area scan detection at $550 \mathrm{~nm}$ wavelength. The results are the mean $\pm \mathrm{SD}$ of 3 independent experiments. ** $p<0.01$, and ${ }^{* * *} p<0.001$ versus control (Student's $t$-test). SD, standard deviation.

Western blotting was used to evaluate the effect of compound 8C on AMPK signaling pathway in T24, one of the most commonly used cell lines. As shown in Figure 6, compound 8C up-regulates p-AMPK and has inhibitory effects on downstream p-mTOR, p-p70S6K and $\mathrm{p}-4 \mathrm{EBP} 1$. 


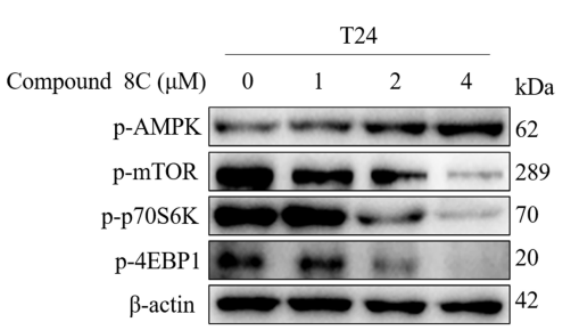

(a)

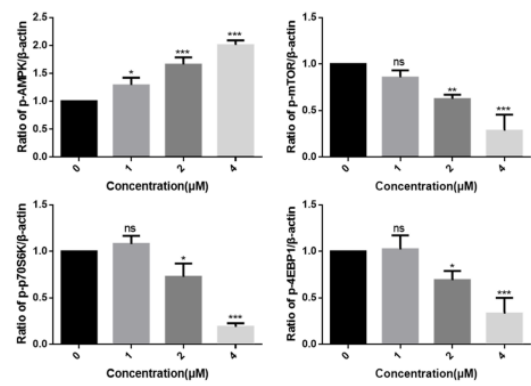

(b)

Figure 6. The effect of compound $8 \mathrm{C}$ on AMPK signaling pathway in T24 cells. T24 cells were inoculated into 6 well plates at a density of $5 \times 10^{5}$ and treated with drugs 24 later. Western blot was used to detect the levels of various signal proteins in T24 cells treated with $8 \mathrm{C}$ at different concentrations for $24 \mathrm{~h}$. The control group was not treated with drugs. (a) Western blot of p-AMPK, p-mTOR, p-p70S6K, p-4EBP1 and $\beta$-actin as an internal reference protein. (b) Relative expression levels of various proteins. The result is the mean $\pm \mathrm{SD}$ of three relatively independent experiments. ${ }^{*} p<0.05,{ }^{* *} p<0.01$, and ${ }^{* *} p<0.001$ versus control (Student's $t$-test). SD, standard deviation.

\section{Discussion}

There are four synthesis routes for preparation of proguanil derivatives [18], we choose the route with highest yield and experimental feasibility as shown in Scheme 1. Ten new compounds were successfully obtained and named $\mathbf{2 C}-\mathbf{1 0 C}$ and $\mathbf{1 2 C}$. The results of MTT demonstrated that $\mathrm{IC}_{50}$ values of $\mathbf{5 C}-\mathbf{8 C}$ are significantly lower than that of proguanil. In contrast, the anti-cancer activities of the derivatives with a longer carbon chain than 8C have decreased significantly, even less than that of proguanil, indicating that there is an optimized carbon chain length in biguanide derivatives. In view of two ovarian cancer cell lines, all compounds have low sensitivity in SKOV3 cell line with less sensitive than that in OVCAR3. Interestingly, the sensitivity of these compounds to three bladder cancer cell lines is similar. In other hand, the results of colony formation demonstrated that $6 \mathrm{C}, 7 \mathrm{C}$ and $8 \mathrm{C}$ have strong anti-clone formation capacities at concentrations between 0.25-1.0 $\mu \mathrm{M}$ while proguanil has no inhibitory effect on colony formation at a concentration of $1.0 \mu \mathrm{M}$ in our previous study [17], indicating that compounds $6 \mathrm{C}, 7 \mathrm{C}$ and $8 \mathrm{C}$ have much better anti-clone formation activities than that of proguanil in T24 and UMUC3. Similar results were obtained in J82, as shown in the Supplemental Information (Figure S4).

Since there is no significant difference in the anti-proliferative activity between $\mathbf{5 C}$ to 8C while compounds with longer carbon chain than $8 \mathrm{C}$ have poorer activity than that of proguanil, we selected the compound $8 \mathrm{C}$ as a representative compound to investigate the pharmacological mechanism. Previously, our research group has proved that biguanide derivatives can exert anti-tumor effects through AMPK/mTOR pathway [19]. Adenosine $5^{\prime}$-monophosphate (AMP)-activated protein kinase (AMPK) is a key molecule in the regulation of bioenergy metabolism [20], and it is the core of the study of diabetes and other metabolic-related diseases [21,22]. It is expressed in various metabolic-related organs and can be activated by various stimuli of the body, including cell pressure, exercise and many hormones and substances that can affect cell metabolism [23-25]. Mammalian target of rapamycin (mTOR) is an important regulator of cell growth and proliferation [26]. A large number of studies have shown that the abnormal regulation of mTOR signaling pathway is closely related to cell proliferation [27-29]. Compound 8C up-regulates p-AMPK and has inhibitory effects on downstream p-mTOR, p-p70S6K and p-4EBP1. Instead, previous studies have shown that proguanil has no effect on the AMPK/mTOR pathway at a concentration of $2.0 \mu \mathrm{M}$ [17]. In this study, compound $8 \mathrm{C}$ can significantly regulate the expression of $\mathrm{AMPK} / \mathrm{mTOR}$ pathway-related proteins at a concentration of $2.0 \mu \mathrm{M}$, indicating a stronger effect of $8 \mathrm{C}$ on $\mathrm{AMPK} / \mathrm{mTOR}$ pathway than that of proguanil. In summary, our data demonstrate that the optimized biguanide derivatives in this study can 
indeed inhibit cancer cell growth associated with the AMPK/mTOR signaling pathway with a more effective activity than that of proguanil.

\section{Materials and Methods}

\subsection{Chemistry}

All solvents and materials are commercial grade and do not require further purification unless otherwise specified. Proton nuclear magnetic resonance $\left({ }^{1} \mathrm{H}-\mathrm{NMR}\right)$ spectra and ${ }^{13} \mathrm{C}$ NMR were recorded on a Brucker DRX spectrometer $(600 \mathrm{MHz})$ in dimethyl sulfoxide (DMSO) solvent by using TMS as an internal standard. High resolution mass spectrometry (HRMS) analysis was performed on an Agilent 1290 HPLC-6540-Q-TOF instrument. The purity of the derivatives was determined by high-performance liquid chromatography (HPLC), conducted on an Agilent 1260 HPLC system with column (Agilent 5 TC-C18(2) $250 \times 4.6 \mathrm{~mm}$ ), and the samples were eluted with a $1: 1$ methanol $/ \mathrm{H}_{2} \mathrm{O}$ mixture, at a flow rate of $1 \mathrm{~mL} / \mathrm{min}$. The melting point of the derivatives was obtained by a micro melting point apparatus XT3A.

\subsubsection{Method for Synthesizing Compound 2}

$\mathrm{NaN}(\mathrm{CN})_{2}(5 \mathrm{~g}, 56 \mathrm{mmol})$ was matched into solution in $43 \mathrm{~mL}$ water, under the condition of $80{ }^{\circ} \mathrm{C}$ to join 4-trifluoro methoxy aniline solution $(7.32 \mathrm{~g}, 30 \mathrm{mmol}$ for 4-trifluoro methoxy aniline, soluble in water and concentrated $\mathrm{HCl} 2.5 \mathrm{~mL} / \mathrm{mL}$ ), $80^{\circ} \mathrm{C}$, continuous reaction $1 \mathrm{~h}$ or so, in the reaction liquid solid precipitation gradually, until the TLC test reaction liquid contains no 4-trifluoro methoxy aniline, at the end of the reaction. 1-cyan-3-(4-(trifluoromethoxy) phenyl) guanidine was obtained by filtration and vacuum drying.

\subsubsection{Method for Synthesizing Compound 2C-10C, $12 \mathrm{C}$}

At room temperature, $1 \mathrm{~g}(4.1 \mathrm{mmol})$ compound 2 was stirred and added to $5 \mathrm{~mL}$ THF and $4 \mathrm{~mL} \mathrm{H}_{2} \mathrm{O}$, followed by $0.7 \mathrm{~g}(2.8 \mathrm{mmol})$ of copper sulfate pentahydrate and $16.4 \mathrm{mmol}$ of alkylamine. It was heat ed to $40{ }^{\circ} \mathrm{C}$ and continued to be stirred. After checking for the presence of compound 2 in the TLC, the tetrahydrofuran was evaporated by vacuum distillation. After cooling the reactant to $25-30{ }^{\circ} \mathrm{C}, \mathrm{HCl}$ solution $(2 \mathrm{~mL}$ concentrated hydrochloric acid in $3 \mathrm{~mL}$ water) was added and stirred for $30 \mathrm{~min}$. Then, dropped cooled ammoniacal EDTA solution ( $3 \mathrm{~mL}$ water, $1.5 \mathrm{~mL}$ ammonia water $(25 \%)$ and $1.4 \mathrm{~g}$ EDTA disodium salt) into the reaction mixture. The temperature range was kept at $15-20{ }^{\circ} \mathrm{C}$. After adding, the product was stirred at the same temperature for $30 \mathrm{~min}$, filtered and separated, washed repeatedly with cold water, dried at $90-95^{\circ} \mathrm{C}$, and solid target product was obtained.

N-1-Ethyl-N-5-(4-trifluoro Methoxy) Proguanil (2C)

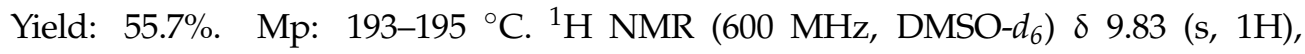
7.54-7.25 (m, 4H), $6.86(\mathrm{~s}, 1 \mathrm{H}), 3.13(\mathrm{q}, J=7.3 \mathrm{~Hz}, 2 \mathrm{H}), 2.75-2.71(\mathrm{~m}, 1 \mathrm{H}), 1.54(\mathrm{~s}, 1 \mathrm{H}), 0.86(\mathrm{td}$, $J=6.0,5.4,3.3 \mathrm{~Hz}, 3 \mathrm{H}) .{ }^{13} \mathrm{C}$ NMR $\left(150 \mathrm{MHz}\right.$, DMSO- $\left.d_{6}\right) \delta 163.98,150.59,143.81,137.93,121.97$, 121.46, 119.77, 31.20, 14.32. HRMS (ESI) $(\mathrm{m} / \mathrm{z})[\mathrm{M}+\mathrm{H}]^{+}$calcd for $\mathrm{C}_{11} \mathrm{H}_{15} \mathrm{~F}_{3} \mathrm{~N}_{5} \mathrm{O}, 290.1229$; found, 290.1218. Purity: 99.74\% (by HPLC).

\section{N-1-Propyl-N-5-(4-trifluoro Methoxy) Proguanil (3C)}

Yield: $52.8 \%$. Mp: $195-196{ }^{\circ} \mathrm{C} .{ }^{1} \mathrm{H}$ NMR $\left(600 \mathrm{MHz}, \mathrm{DMSO}-d_{6}\right) \delta 8.16(\mathrm{~s}, 1 \mathrm{H})$, 7.58-7.19 (m, 5H), $3.04(\mathrm{t}, J=7.2 \mathrm{~Hz}, 2 \mathrm{H}), 1.46(\mathrm{~s}, 2 \mathrm{H}), 0.92-0.79(\mathrm{~m}, 3 \mathrm{H}) .{ }^{13} \mathrm{C}$ NMR $\left(150 \mathrm{MHz}, \mathrm{DMSO}-d_{6}\right) \delta 161.62,155.91,143.61,138.96,123.16,122.23,121.64,119.77,118.08$, 40.51, 22.99, 11.69. HRMS (ESI) $(m / z)[\mathrm{M}+\mathrm{H}]^{+}$calcd for $\mathrm{C}_{12} \mathrm{H}_{17} \mathrm{~F}_{3} \mathrm{~N}_{5} \mathrm{O}, 304.1385$; found, 304.1396. Purity: $97.75 \%$ (by HPLC). 
N-1-Butyl-N-5-(4-trifluoro Methoxy) Proguanil (4C)

Yield: 53.5\%. Mp: $197-199{ }^{\circ} \mathrm{C} .{ }^{1} \mathrm{H}$ NMR $\left(600 \mathrm{MHz}, \mathrm{DMSO}-d_{6}\right) \delta 9.83(\mathrm{~s}, 1 \mathrm{H}), 8.06(\mathrm{~s}, 1 \mathrm{H})$, 7.53-7.25 (m, 5H), $6.85(\mathrm{~s}, 1 \mathrm{H}), 3.09(\mathrm{~d}, J=7.3 \mathrm{~Hz}, 2 \mathrm{H}), 1.47(\mathrm{~s}, 2 \mathrm{H}), 1.31(\mathrm{~d}, J=9.2 \mathrm{~Hz}, 2 \mathrm{H})$, 0.92-0.81 (m, 3H). ${ }^{13} \mathrm{C}$ NMR $\left(150 \mathrm{MHz}\right.$, DMSO- $\left.d_{6}\right) \delta 160.84,157.45,144.78,143.73,123.41$, $122.14,121.95,121.46,119.76,41.95,30.46,19.97,14.05$. HRMS (ESI) $(m / z)[\mathrm{M}+\mathrm{H}]^{+}$calcd for $\mathrm{C}_{13} \mathrm{H}_{19} \mathrm{~F}_{3} \mathrm{~N}_{5} \mathrm{O}$, 318.1542; found, 318.1541. Purity: 97.52\% (by HPLC).

N-1-Amyl-N-5-(4-trifluoro Methoxy) Proguanil (5C)

Yield: $52.9 \%$. Mp: $196-198{ }^{\circ} \mathrm{C} .{ }^{1} \mathrm{H}$ NMR $\left(600 \mathrm{MHz}\right.$, DMSO- $\left.d_{6}\right) \delta 8.06(\mathrm{~s}, 1 \mathrm{H}), 7.51-7.26$ $(\mathrm{m}, 5 \mathrm{H}), 6.87(\mathrm{~s}, 1 \mathrm{H}), 3.08(\mathrm{q}, J=6.6 \mathrm{~Hz}, 2 \mathrm{H}), 1.53-1.38(\mathrm{~m}, 2 \mathrm{H}), 1.33-1.18(\mathrm{~m}, 4 \mathrm{H}), 0.85$ $(\mathrm{dq}, J=11.3,6.2 \mathrm{~Hz}, 3 \mathrm{H}) .{ }^{13} \mathrm{C}$ NMR $\left(150 \mathrm{MHz}, \mathrm{DMSO}-d_{6}\right) \delta 160.72,157.48,143.76,138.91$, $123.15,121.94,121.46,119.76,42.21,28.93,28.07,22.23,14.31$. HRMS (ESI) $(m / z)[\mathrm{M}+\mathrm{H}]^{+}$ calcd for $\mathrm{C}_{14} \mathrm{H}_{21} \mathrm{~F}_{3} \mathrm{~N}_{5} \mathrm{O}$, 332.1698; found, 332.1695. Purity: $96.17 \%$ (by HPLC).

N-1-Hexyl-N-5-(4-trifluoro Methoxy) Proguanil (6C)

Yield: 49.3\%. Mp: 206-208 ${ }^{\circ} \mathrm{C} .{ }^{1} \mathrm{H}$ NMR $\left(600 \mathrm{MHz}, \mathrm{DMSO}-d_{6}\right) \delta 9.76(\mathrm{~s}, 1 \mathrm{H}), 7.39$ (dd, $J=119.5,8.6 \mathrm{~Hz}, 5 \mathrm{H}), 6.84(\mathrm{~s}, 1 \mathrm{H}), 3.08(\mathrm{q}, J=7.3,6.5 \mathrm{~Hz}, 2 \mathrm{H}), 1.27(\mathrm{~s}, 8 \mathrm{H}), 0.86(\mathrm{~s}, 3 \mathrm{H})$. 13C NMR (150 MHz, DMSO- $\left.d_{6}\right) \delta 160.81,160.36,143.75,138.93,122.12,121.93,121.46$, $119.76,118.07,41.46,31.36,29.63,26.41,22.48,14.36$. HRMS (ESI) $(m / z)[\mathrm{M}+\mathrm{H}]^{+}$calcd for $\mathrm{C}_{15} \mathrm{H}_{23} \mathrm{~F}_{3} \mathrm{~N}_{5} \mathrm{O}$, 346.1855; found, 346.1908. Purity: $97.94 \%$ (by HPLC).

N-1-Heptyl-N-5-(4-trifluoro Methoxy) Proguanil (7C)

Yield: $43.5 \%$. Mp: $210-212{ }^{\circ} \mathrm{C} .{ }^{1} \mathrm{H}$ NMR $\left(600 \mathrm{MHz}\right.$, DMSO- $\left.d_{6}\right) \delta 7.40(\mathrm{dd}, J=124.3$, $8.8 \mathrm{~Hz}, 5 \mathrm{H}), 6.86(\mathrm{~s}, 1 \mathrm{H}), 3.09(\mathrm{~s}, 2 \mathrm{H}), 1.25(\mathrm{~s}, 10 \mathrm{H}), 0.87(\mathrm{t}, J=6.7 \mathrm{~Hz}, 3 \mathrm{H}) .{ }^{13} \mathrm{C}$ NMR (150 MHz, DMSO-d 6 ) 8160.79, 154.14, 143.73, 138.96, 121.91, 121.46, 119.77, 42.24, 31.65, 28.80, 27.42, 26.27, 22.51, 14.40. HRMS (ESI) $(m / z)[\mathrm{M}+\mathrm{H}]^{+}$calcd for $\mathrm{C}_{16} \mathrm{H}_{25} \mathrm{~F}_{3} \mathrm{~N}_{5} \mathrm{O}, 360.2011$; found, 360.2016. Purity: $98.30 \%$ (by HPLC).

N-1-Octyl-N-5-(4-trifluoro Methoxy) Proguanil (8C)

Yield: $45.7 \%$. Mp: $214-216{ }^{\circ} \mathrm{C} .{ }^{1} \mathrm{H}$ NMR $\left(600 \mathrm{MHz}, \mathrm{DMSO}-d_{6}\right) \delta 9.80(\mathrm{~s}, 1 \mathrm{H})$, 7.51-7.23 (m, 5H), $6.83(\mathrm{~s}, 1 \mathrm{H}), 3.08-3.03(\mathrm{~m}, 2 \mathrm{H}), 1.34(\mathrm{~d}, J=132.7 \mathrm{~Hz}, 12 \mathrm{H}), 0.86-0.81(\mathrm{~m}, 3 \mathrm{H})$. ${ }^{13} \mathrm{C}$ NMR $\left(150 \mathrm{MHz}, \mathrm{DMSO}-d_{6}\right) \delta 160.77,154.13,143.74,138.95,122.12,122.04,121.91$, $121.46,119.77,42.22,31.71,29.67,29.09,28.40,26.76,22.54,14.40$. HRMS (ESI) $(m / z)[\mathrm{M}+\mathrm{H}]^{+}$ calcd for $\mathrm{C}_{17} \mathrm{H}_{27} \mathrm{~F}_{3} \mathrm{~N}_{5} \mathrm{O}$, 374.2168; found, 374.2185. Purity: 99.70\% (by HPLC).

N-1-Nonyl-N-5-(4-trifluoro Methoxy) Proguanil (9C)

Yield: $42.9 \%$. Mp: $213-215{ }^{\circ} \mathrm{C} .{ }^{1} \mathrm{H}$ NMR $\left(600 \mathrm{MHz}, \mathrm{DMSO}-d_{6}\right) \delta 7.74-7.05(\mathrm{~m}$, $4 \mathrm{H}), 6.84(\mathrm{~s}, 1 \mathrm{H}), 3.19-3.02(\mathrm{~m}, 2 \mathrm{H}), 1.24(\mathrm{~s}, 14 \mathrm{H}), 0.84(\mathrm{tq}, J=8.5,3.8,3.2 \mathrm{~Hz}, 3 \mathrm{H})$ ${ }^{13} \mathrm{C}$ NMR $\left(150 \mathrm{MHz}\right.$, DMSO- $\left.d_{6}\right) \delta 160.29,153.80,144.13,135.66,123.08,121.86,119.68$, $49.06,31.70,29.72,29.35,29.11,29.10,22.92,22.53,14.38$. HRMS (ESI) $(m / z)[\mathrm{M}+\mathrm{H}]^{+}$calcd for $\mathrm{C}_{18} \mathrm{H}_{29} \mathrm{~F}_{3} \mathrm{~N}_{5} \mathrm{O}$, 388.2324; found, 388.2326. Purity: $100.00 \%$ (by HPLC).

N-1-Decyl-N-5-(4-trifluoro Methoxy) Proguanil (10C)

Yield: 41.2\%. Mp: 216-218 ${ }^{\circ} \mathrm{C} .{ }^{1} \mathrm{H}$ NMR $\left(600 \mathrm{MHz}\right.$, DMSO- $\left.d_{6}\right) \delta 9.78(\mathrm{~s}, 1 \mathrm{H}), 7.59-7.09$ (m, $5 \mathrm{H}), 6.86(\mathrm{~s}, 1 \mathrm{H}), 3.14(\mathrm{q}, J=7.3 \mathrm{~Hz}, 2 \mathrm{H}), 2.75(\mathrm{t}, J=7.6 \mathrm{~Hz}, 2 \mathrm{H}), 1.58-1.02(\mathrm{~m}, 14 \mathrm{H}), 0.87(\mathrm{t}$, $J=6.8 \mathrm{~Hz}, 3 \mathrm{H}) .{ }^{13} \mathrm{C}$ NMR $\left(150 \mathrm{MHz}\right.$, DMSO- $\left.d_{6}\right) \delta 160.39,155.89,143.64,137.72,121.74,119.77$, $118.07,46.00,31.76,29.37,29.33,29.16,29.05,27.68,26.38,22.56,14.40$. HRMS (ESI) $(m / z)[\mathrm{M}+\mathrm{H}]^{+}$ calcd for $\mathrm{C}_{19} \mathrm{H}_{31} \mathrm{~F}_{3} \mathrm{~N}_{5} \mathrm{O}$, 402.2481; found, 402.2482. Purity: 99.53\% (by HPLC).

N-1-Dodecyl-N-5-(4-trifluoro Methoxy) Proguanil (12C)

Yield: 40.8\%. Mp: $225-227^{\circ} \mathrm{C} .{ }^{1} \mathrm{H}$ NMR (600 MHz, DMSO- $\left.d_{6}\right) \delta 9.06$ (s, $\left.1 \mathrm{H}\right), 7.38-6.67$ $(\mathrm{m}, 4 \mathrm{H}), 4.79(\mathrm{~s}, 1 \mathrm{H}), 4.04(\mathrm{q}, J=7.1 \mathrm{~Hz}, 2 \mathrm{H}), 2.00(\mathrm{~s}, 2 \mathrm{H}), 1.42-1.22(\mathrm{~m}, 18 \mathrm{H}), 1.18(\mathrm{t}, J=7.1 \mathrm{~Hz}$, 3H). ${ }^{13} \mathrm{C}$ NMR (150 MHz, DMSO-d 6 ) $\delta 153.82,147.55,147.35,138.99,124.84,124.61,123.63$, $123.18,119.48,60.23,34.93,34.77,32.01,31.76,31.66,30.82,30.61,29.89,29.48,22.57,21.23,14.55$. 
HRMS (ESI) $(m / z)[\mathrm{M}+\mathrm{H}]^{+}$calcd for $\mathrm{C}_{21} \mathrm{H}_{35} \mathrm{~F}_{3} \mathrm{~N}_{5} \mathrm{O}$, 430.2794; found, 430.2825. Purity: $98.76 \%$ (by HPLC).

\subsection{Biological Evaluation \\ 4.2.1. Reagents}

Each new compound was dissolved in DMSO to prepare a stock solution of $20 \mathrm{mmol} / \mathrm{L}$. Antibodies for the protein characterization against phosphor-AMPK (Thr172), phosphormTOR (S2448), phosphor-p70S6 kinase (Thr389), phosphor-4EBP1 (Thr-70) and $\beta$-actin were purchased from Cell Signaling Technology.

\subsubsection{Cell Lines and Culture Conditions}

Three human bladder cancer cell lines (T24, UMUC3, J82) were obtained from Dr. Guo Peng (Xi'an Jiaotong University, Xi'an, China). The human ovarian cancer cell line (SKOV3) was gifted by Dr. Zhang Yong from Xiangya Hospital, Changsha, China. The human ovarian cancer cell line (OVCAR3) was purchased from ATCC. All cells were cultured in DMEM (Hyclone, Logan, UT, USA), MEM (Hyclone, Logan, UT, USA) or RPMI-1640 (Hyclone, Logan, UT, USA) medium, and the medium was supplemented with $10 \%$ fetal bovine serum (Hyclone, Logan, UT, USA) and 1\% penicillin/streptomycin mixture. The cells were cultured in a $37^{\circ} \mathrm{C}, 5 \% \mathrm{CO}_{2}$ humidified incubator.

\subsubsection{MTT Cell Viability Assay}

The cell seed plate was cultured overnight in a 96 well plates (6000 cells/well), and then different concentrations of compounds were added and treated for $72 \mathrm{~h}$. A total of $50 \mu \mathrm{L}$ of $2 \mathrm{mg} / \mathrm{mL}$ MTT was added to each well, incubated for $6 \mathrm{~h}$ in an incubator, removed the medium, $150 \mu \mathrm{L}$ of DMSO was added to each well, and then the absorbance of each well at $490 \mathrm{~nm}$ was measured with a microplate reader (Biotek, SYNERGY HTX, Winooski, VT, USA). The absorbance of the cells without drug treatment was set to $100 \%$, the relative survival rate of the cells was calculated, and the $\mathrm{IC}_{50}$ value was calculated using SPSS.

\subsubsection{Clonogenic Assay}

The cells were seeded in a 24 well plates at a density of 1000 cells/well. After $24 \mathrm{~h}$, different concentrations of compounds were added and treated for 6-8 days. Cells were fixed with $10 \%$ paraformaldehyde, stained with $0.1 \%$ crystal violet, and the absorbance of each well was measured by scanning the area at $550 \mathrm{~nm}$ with a microplate reader (Biotek, SYNERGY HTX, Winooski, VT, USA).

\subsubsection{Western Blot Analysis}

The cells are extracted from the protein extract solution, separated by sodium dodecyl sulfate polyacrylamide gel electrophoresis, and then transferred to a polyvinylidene fluoride (PVDF) membrane. They were blocked with $5 \%$ milk, placed the membrane at $4{ }^{\circ} \mathrm{C}$ to bind with the specific primary antibody for $15-18 \mathrm{~h}$ and then, rinsed with phosphate buffer containing $0.1 \%$ Tween; the secondary antibody was incubated for $1 \mathrm{~h}$, and then rinsed with PBST. The Pierce super signal chemiluminescence substrate was added, and immediately the Chemi Doc system was used for blot imaging (Bio-Rad, Hercules, CA, USA). ImageJ software was used to perform grayscale analysis, and compared with the control group, and the expression level of related proteins was normalized through the expression of the internal reference protein.

\subsubsection{Statistical Analyses}

All data were statistically analyzed using the Bonferroni test function of SPSS software and GraphPad Prism software. The two groups of experiments used Student's $t$-test, and the two or more groups used one-way analysis of variance to evaluate the significance of differences between the groups. The graph was generated using GraphPad Prism 6.0 software. ${ }^{*} p<0.05,{ }^{* *} p<0.01$, and ${ }^{* * *} p<0.001$. 


\section{Conclusions}

In summary, we designed and synthesized 10 biguanide compounds containing trifluoromethoxy group, fixed the trifluoromethoxy group on one side of the benzene ring of the biguanide group and changed the side chain on the other side. The anti-proliferative activities of the synthesized compounds were tested; we found that there is an optimized carbon chain length in the range from $6 \mathrm{C}$ to $8 \mathrm{C}$ with maximum anti-proliferative activities. In order to further explore the anti-tumor mechanism of the compound, Western blot results show that compound $8 \mathrm{C}$ (n-octyl) has a dramatic effect on the AMPK-mTOR signal pathway. Therefore, on the basis of this study, we came to a conclusion that for the structural modification of biguanide derivatives, when the carbon chain is in the range of $n$-amyl to n-octyl, the biguanide derivatives have maximum anti-proliferative activities, which will guide the subsequent development of biguanide compounds in future. In meantime, we believe that $8 \mathrm{C}$ is a promising anti-cancer drug targeting the AMPK pathway, which is worthy of further study.

Supplementary Materials: The following are available online at, Figure S1: NMR spectra of target derivatives, Figure S2: HPLC chromatograms of target derivatives, Figure S3: High Resolution Mass spectra of target derivatives, Figure S4: Clonogenic assay.

Author Contributions: Conceptualization, S.X., Y.C. and X.Y.; methodology, S.X., Y.C. and Y.L.; software, S.X. and Y.C.; validation, D.X., W.W., Z.W. and X.Y.; formal analysis, S.X. and Y.C.; resources, X.Y.; data curation, X.Y.; writing—original draft preparation, S.X. and Y.C.; writing-review and editing, X.Y.; supervision, X.Y.; project administration, X.Y. All authors have read and agreed to the published version of the manuscript.

Funding: This work was supported by the National Natural Science Foundation of China (No. 81874212, 82172653); Huxiang High-Level Talent Innovation Team (2018RS3072); Opening Fund for Key Laboratory of Molecular Pharmacology and Drug Evaluation (Yantai University), Ministry of Education (P201905); Scientific and Technological Projects for Collaborative Prevention and Control of Birth Defect in Hunan Province (2019SK1012) and Key Grant of Research and Development in Hunan Province (2020DK2002).

Institutional Review Board Statement: Not applicable.

Informed Consent Statement: Not applicable.

Data Availability Statement: The data presented in this study are available in supplementary material.

Acknowledgments: This work was supported by the National Natural Science Foundation of China and the Hunan Provincial Science and Technology Department.

Conflicts of Interest: The authors declare that there is no conflict of interest.

Sample Availability: Samples of the synthesized compounds are available from the authors.

\section{References}

1. Sung, H.; Ferlay, J.; Siegel, R.L.; Laversanne, M.; Soerjomataram, I.; Jemal, A.; Bray, F. Global Cancer Statistics 2020: GLOBOCAN Estimates of Incidence and Mortality Worldwide for 36 Cancers in 185 Countries. CA Cancer J. Clin. 2021, 71, 209-249. [CrossRef] [PubMed]

2. Bailey, C.J. Metformin: Historical overview. Diabetologia 2017, 60, 1566-1576. [CrossRef]

3. JKilgore, J.; Jackson, A.L.; Clark, L.H.; Guo, H.; Zhang, L.; Jones, H.M.; Gilliam, T.P.; Gehrig, P.A.; Zhou, C.; Bae-Jump, V.L. Buformin exhibits anti-proliferative and anti-invasive effects in endometrial cancer cells. Am. J. Transl. Res. 2016, 8, $2705-2715$.

4. Mounkoro, P.; Michel, T.; Meunier, B. Revisiting the mode of action of the antimalarial proguanil using the yeast model. Biochem. Biophys. Res. Commun. 2021, 534, 94-98. [CrossRef] [PubMed]

5. Gabel, S.A.; Duff, M.R.; Pedersen, L.C.; Derose, E.F.; Krahn, J.M.; Howell, E.E.; London, R.E. A Structural Basis for Biguanide Activity. Biochemistry 2017, 56, 4786-4798. [CrossRef]

6. Xu, S.; Feliu, M.; Lord, A.K.; Lukason, D.; Negoro, P.E.; Khan, N.S.; Dagher, Z.; Feldman, M.B.; Reedy, J.L.; Steiger, S.N.; et al. Biguanides enhance antifungal activity against Candida glabrata. Virulence 2018, 9, 1150-1162. [CrossRef] [PubMed]

7. Zhu, Z.; Jiang, W.; Thompson, M.D.; Echeverria, D.; McGinley, J.N.; Thompson, H.J. Effects of Metformin, Buformin, and Phenformin on the Post-Initiation Stage of Chemically Induced Mammary Carcinogenesis in the Rat. Cancer Prev. Res. 2015, 8, 518-527. [CrossRef] 
8. Lea, M.A.; Kim, H.; Desbordes, C. Effects of Biguanides on Growth and Glycolysis of Bladder and Colon Cancer Cells. Anticancer Res. 2018, 38, 5003-5011. [CrossRef]

9. SBurmaoglu, S.; Algul, O.; Anıl, D.A.; Gobek, A.; Duran, G.G.; Ersan, R.H.; Duran, N. Synthesis and anti-proliferative activity of fluoro-substituted chalcones. Bioorg. Med. Chem. Lett. 2016, 26, 3172-3176. [CrossRef] [PubMed]

10. Lagu, S.B.; Yejella, R.P.; Bhandare, R.R.; Shaik, A.B. Design, Synthesis, and Antibacterial and Antifungal Activities of Novel Trifluoromethyl and Trifluoromethoxy Substituted Chalcone Derivatives. Pharmaceuticals 2020, 13, 375. [CrossRef]

11. Leroux, F.R.; Manteau, B.; Vors, J.-P.; Pazenok, S. Trifluoromethyl ethers-Synthesis and properties of an unusual substituent. Beilstein J. Org. Chem. 2008, 4, 13. [CrossRef]

12. Xing, L.; Blakemore, D.C.; Narayanan, A.; Unwalla, R.; Lovering, F.; Denny, R.A.; Zhou, H.; Bunnage, M.E. Fluorine in Drug Design: A Case Study with Fluoroanisoles. ChemMedChem 2015, 10, 715-726. [CrossRef]

13. Mandal, D.; Gupta, R.; Jaiswal, A.K.; Young, R.D. Frustrated Lewis-Pair-Meditated Selective Single Fluoride Substitution in Trifluoromethyl Groups. J. Am. Chem. Soc. 2020, 142, 2572-2578. [CrossRef]

14. Wang, L.; Wei, J.; Wu, R.; Cheng, G.; Li, X.; Hu, J.; Hu, Y.; Sheng, R. The stability and reactivity of tri-, di-, and monofluoromethyl/methoxy/methylthio groups on arenes under acidic and basic conditions. Org. Chem. Front. 2017, 4, 214-223. [CrossRef]

15. Deb, U.; Biswas, S. Pretomanid: The latest USFDA-approved anti-tuberculosis drug. Indian J. Tuberc. 2021, 68, 287-291. [CrossRef] [PubMed]

16. Brancaccio, G.; Pea, F.; Moscarella, E.; Argenziano, G. Sonidegib for the Treatment of Advanced Basal Cell Carcinoma. Front. Oncol. 2020, 10, 582866. [CrossRef] [PubMed]

17. Xiao, D.; Lu, Z.; Wang, Z.; Zhou, S.; Cao, M.; Deng, J.; Hu, X.; Peng, M.; He, C.; Wu, J.; et al. Synthesis, biological evaluation and anti-proliferative mechanism of fluorine-containing proguanil derivatives. Bioorg. Med. Chem. 2020, 28, 115258. [CrossRef] [PubMed]

18. Kathuria, D.; Raul, A.D.; Wanjari, P.; Bharatam, P.V. Biguanides: Species with versatile therapeutic applications. Eur. J. Med. Chem. 2021, 219, 113378. [CrossRef]

19. Zhou, S.; Xu, L.; Cao, M.; Wang, Z.; Xiao, D.; Xu, S.; Deng, J.; Hu, X.; He, C.; Tao, T.; et al. Anticancer properties of novel pyrazole-containing biguanide derivatives with activating the adenosine monophosphate-activated protein kinase signaling pathway. Arch. Pharm. 2019, 352, e1900075. [CrossRef]

20. Carling, D. AMPK signalling in health and disease. Curr. Opin. Cell Biol. 2017, 45, 31-37. [CrossRef]

21. Song, P.; Hwang, J.S.; Park, H.C.; Kim, K.K.; Son, H.-J.; Kim, Y.-J.; Lee, K.M. Therapeutic Applications of Type 2 Diabetes Mellitus Drug Metformin in Patients with Osteoarthritis. Pharmaceuticals 2021, 14, 152. [CrossRef]

22. Klein, J.D.; Khanna, I.; Pillarisetti, R.; Hagan, R.A.; LaRocque, L.M.; Rodriguez, E.L.; Sands, J.M. An AMPK activator as a therapeutic option for congenital nephrogenic diabetes insipidus. JCI Insight 2021, 6, e146419. [CrossRef]

23. Bheemanapally, K.; Ibrahim, M.M.H.; Alshamrani, A.; Briski, K.P. Ventromedial hypothalamic nucleus glycogen regulation of metabolic-sensory neuron AMPK and neurotransmitter expression: Role of lactate. Am. J. Physiol. Regul. Integr. Comp. Physiol. 2021, 320, R791-R799. [CrossRef] [PubMed]

24. Rodríguez, C.; Muñoz, M.; Contreras, C.; Prieto, D. AMPK, metabolism, and vascular function. FEBS J. 2021, $288,3746-3771$. [CrossRef] [PubMed]

25. Zhou, S.; Obianom, O.; Huang, J.; Guo, D.; Yang, H.; Li, Q.; Shu, Y. Pyrvinium Treatment Confers Hepatic Metabolic Benefits via $\beta$-Catenin Downregulation and AMPK Activation. Pharmaceutics 2021, 13, 330. [CrossRef] [PubMed]

26. Liu, G.Y.; Sabatini, D.M. mTOR at the nexus of nutrition, growth, ageing and disease. Nat. Rev. Mol. Cell Biol. 2020, 21, 183-203. [CrossRef] [PubMed]

27. Magnuson, B.; Ekim, B.; Fingar, D.C. Regulation and function of ribosomal protein S6 kinase (S6K) within mTOR signalling networks. Biochem. J. 2011, 441, 1-21. [CrossRef]

28. Li, Z.; Li, C.; Wu, Q.; Tu, Y.; Wang, C.; Yu, X.; Li, B.; Wang, Z.; Sun, S.; Sun, S. MEDAG enhances breast cancer progression and reduces epirubicin sensitivity through the AKT/AMPK/mTOR pathway. Cell Death Dis. 2021, 12, 1-15. [CrossRef]

29. Xie, G.; Sun, L.; Li, Y.; Chen, B.; Wang, C. Periplocin inhibits the growth of pancreatic cancer by inducing apoptosis via AMPK-mTOR signaling. Cancer Med. 2021, 10, 325-336. [CrossRef] [PubMed] 